\title{
Editorial
}

Misconceptions and ill-founded theories can arise in all areas of science. However, the apparent accessibility of many epidemiology findings and popular interest in the subject can lead to additional misunderstandings. The article below begins an occasional series of short editorials highlighting some current misinterpretations of epidemiological findings. Invited authors will be given wide scope in judging the prevalence of the misconception under discussion. It is hoped that, by its careful examination of appropriate methods and the relevant data, this series will prove instructive to cancer researchers in a wide range of disciplines and to students of epidemiology.

\section{That rising obesity levels will greatly add to the burden of cancer: misconceptions I}

\author{
BJ Cairns*,', TYO Yang' and V Beral' \\ 'Cancer Epidemiology Unit, University of Oxford, Richard Doll Building, Roosevelt Drive, Oxford OX3 7LF, UK
}

British Journal of Cancer (20II) I 04, 4-5. doi:I0.1038/sj.bjc.6606024 www.bjcancer.com

(c) 20II Cancer Research UK

Projections of future obesity levels, based on the well-documented increases during the twentieth century (James et al, 2001), have been described as a potential 'public health catastrophe' (James et al, 2004). Cancer is often highlighted as one of the major health problems linked to excess adiposity. However, most of the obesityrelated burden of disease comes from diabetes and cardiovascular disease: only about one-tenth is estimated to be due to cancer (Allender and Rayner, 2007).

Obesity is associated with increases in cancer at a number of sites (Calle and Kaaks, 2004; Reeves et al, 2007; Renehan et al, 2008; Prospective Studies Collaboration, 2009). Overall, a $1 \mathrm{~kg} \mathrm{~m}^{-2}$ increase in body mass index (BMI) is associated with an approximately $1 \%$ increase in incidence for all cancers combined (based on data from women; Reeves et al, 2007) and about a $2 \%$ increase in total cancer mortality (based largely on data from men; Prospective Studies Collaboration, 2009). Endometrial cancer and oesophageal adenocarcinoma are the malignancies most strongly related to obesity, each being associated with about a $10 \%$ increase in incidence per $1 \mathrm{~kg} \mathrm{~m}^{-2}$ increase in BMI. There are weaker associations with postmenopausal breast cancer, colon cancer in men, renal cell carcinoma and certain other cancers. In contrast, for premenopausal breast cancer, lung cancer and squamous cell carcinoma of the oesophagus, risk decreases with increasing BMI (Renehan et al, 2008).

During the latter half of the twentieth century, the mean BMI of many Western populations increased by around $1 \mathrm{~kg} \mathrm{~m}^{-2}$ per decade (Prospective Studies Collaboration, 2009), although the rate of increase now appears to be slowing (Cairns et al, 2009; Joint Health Surveys Unit, 2009; Brown et al, 2010; Howel, 2010) (see Figure 1). We might expect, other things being equal, that the $1 \mathrm{~kg} \mathrm{~m}^{-2}$ per decade increase in BMI should have resulted in $1-2 \%$ per decade increases in overall cancer incidence and mortality,

*Correspondence: Dr BJ Cairns; E-mail: ben.cairns@ceu.ox.ac.uk

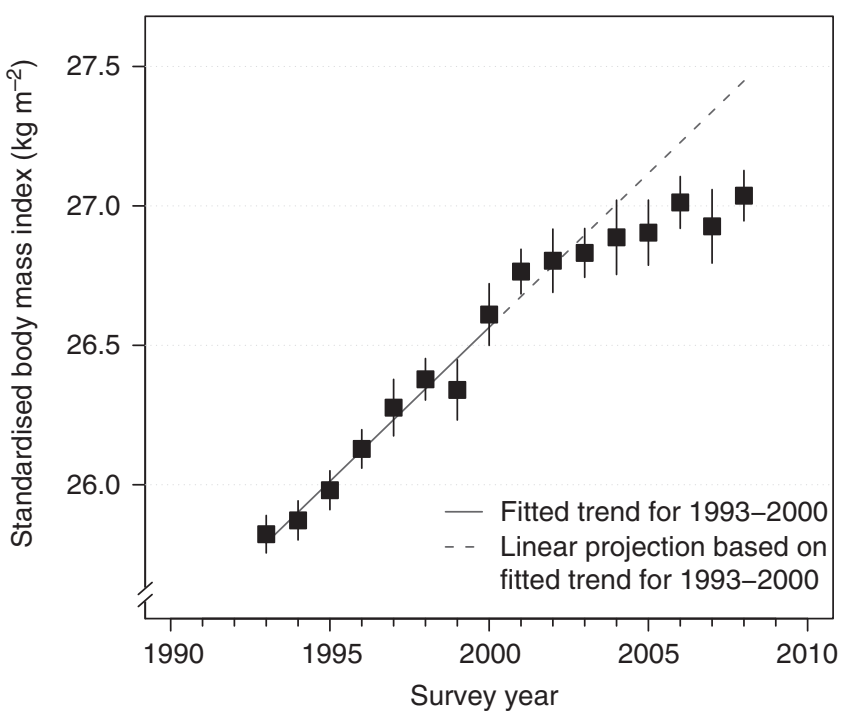

Figure I Mean body mass index and $95 \% \mathrm{Cls}$ standardised by age and sex, for adults in England, 1993-2008. Age- and sex-specific mean values (Joint Health Surveys Unit, 2009) were standardised according to the 200 I Census population (Office for National Statistics, 200 I).

although site-specific trends will have varied. This increase is small compared with the effects of changes in other risk factors, such as smoking, and improved cancer detection and treatment (Jemal et al, 2008; La Vecchia et al, 2009). The obesity epidemic is therefore unlikely to add greatly to the overall burden of cancer.

\section{Conflict of interest}

The authors declare no conflict of interest. 


\section{REFERENCES}

Allender S, Rayner M (2007) The burden of overweight and obesity-related ill health in the UK. Obesity Rev 8: 467-473

Brown M, Byatt T, Marsh T, McPherson K (2010) Obesity trends for adults: analysis from the Health Survey for England 1993-2007. National Heart Forum. Available online at: http://www.heartforum.org.uk/resources/ nhf-publications/?entryid30 $=3985 \&$ char $=0$.

Cairns BJ, Spencer EA, Beral V (2009) Rise in obesity slower since the turn of the century among adults in England: BMJ Rapid Response to: Kmietowicz, Z (2009). Rise in obesity among children in England may be slowing. BMJ 339: b4568. Available online at: http://www.bmj.com/ content/339/bmj.b4568.short/reply\#bmj_el_226995

Calle EE, Kaaks R (2004) Overweight, obesity and cancer: epidemiological evidence and proposed mechanisms. Nat Rev Cancer 4: 579-591

Howel D (2010) Trends in the prevalence of obesity and overweight in English adults by age and birth cohort, 1991-2006. Public Health Nutr, (E-pub ahead of print 26 March 2010) doi:10.1017/S136898001000056X

James PT, Leach R, Kalamara E, Shayeghi M (2001) The worldwide obesity epidemic. Obesity 9: $228 \mathrm{~S}-233 \mathrm{~S}$

James PT, Rigby N, Leach R (2004) The obesity epidemic, metabolic syndrome and future prevention strategies. Eur J Cardiovasc Prev Rehabil 11: 3-8

Jemal A, Thun MJ, Ries LAG, Howe HL, Weir HK, Center MM, Ward E, Wu X-C, Eheman C, Anderson R, Ajani UA, Kohler B, Edwards BK (2008) Annual Report to the Nation on the Status of Cancer, 1975-2005, featuring trends in lung cancer, tobacco use, and tobacco control. J Natl Cancer Inst 100: 1672-1694

Joint Health Surveys Unit (2009) Health Survey for England 2008: Trend tables: The Health and Social Care Information Centre (computer file). Available online at: http://www.ic.nhs.uk/statistics-and-data-collections/ health-and-lifestyles-related-surveys/health-survey-for-england/health-surveyfor-england-2008-trend-tables

La Vecchia C, Bosetti C, Lucchini F, Bertuccio P, Negri E, Boyle P, Levi F (2009) Cancer mortality in Europe, 2000-2004, and an overview of trends since 1975. Ann Oncol 21: $1323-1360$

Office for National Statistics (2001) 2001 Census: Standard Area Statistics (England and Wales) [computer file]. ESRC/JISC Census Programme, Census Dissemination Unit, Mimas (University of Manchester), Manchester, UK

Prospective Studies Collaboration (2009) Body-mass index and causespecific mortality in 900000 adults: collaborative analyses of 57 prospective studies. Lancet 373: $1083-1096$

Reeves GK, Pirie K, Beral V, Green J, Spencer E, Bull D, Million Women Study C (2007) Cancer incidence and mortality in relation to body mass index in the Million Women Study: cohort study. $\mathrm{Br}$ Med J 335: $1134-1139$

Renehan AG, Tyson M, Egger M, Heller RF, Zwahlen M (2008) Body-mass index and incidence of cancer: a systematic review and meta-analysis of prospective observational studies. Lancet 371: 569-578 